\title{
Content Usage and the Most Frequently Read Articles in 2009
}

Once again we provide feedback about the fournal of the American Board of Family Medicine articles of greatest interest to our readers during the previous calendar year. Figure 1 illustrates both the number of total access events and full-text HTML and PDFs throughout 2009; a new issue is published bimonthly (this is also noted in the figure). With an average of almost 197,000 monthly and a total of 2.3 million yearly content usage requests, 2009 proved to be the busiest year for online usage activity in $7 A B F M$ 's history. Content activity was up

Conflict of interest: The authors are editors and staff of the 7ABFM.
$15 \%$ in 2009 when compared with content usage requests during 2008. ${ }^{1}$ Full-text HTML articles were the most accessed during 2009, with an average of 79,700 monthly requests, followed by abstracts with 48,300 average monthly requests and then PDF articles, with 46,000 average monthly requests. We thank you, our reading community, for your continued support of the $7 A B F M$.

Table 1 shows the top 20 most frequently read articles in the $7 A B F M$ for January 2009 through December 2009. Specific articles continue to be relevant to readers; $75 \%$ of the articles appeared on the 2008 top 20 list as well. ${ }^{1}$ The majority of the articles were published in 2006 or earlier; this

Figure 1.Journal of the American Board of Family Medicine online content usage by month, 2009. (Data from HighWire Press. Year-to-date usage summary for the JABFM. Produced 8 Feb 2010. Accessed 12 March 2010).

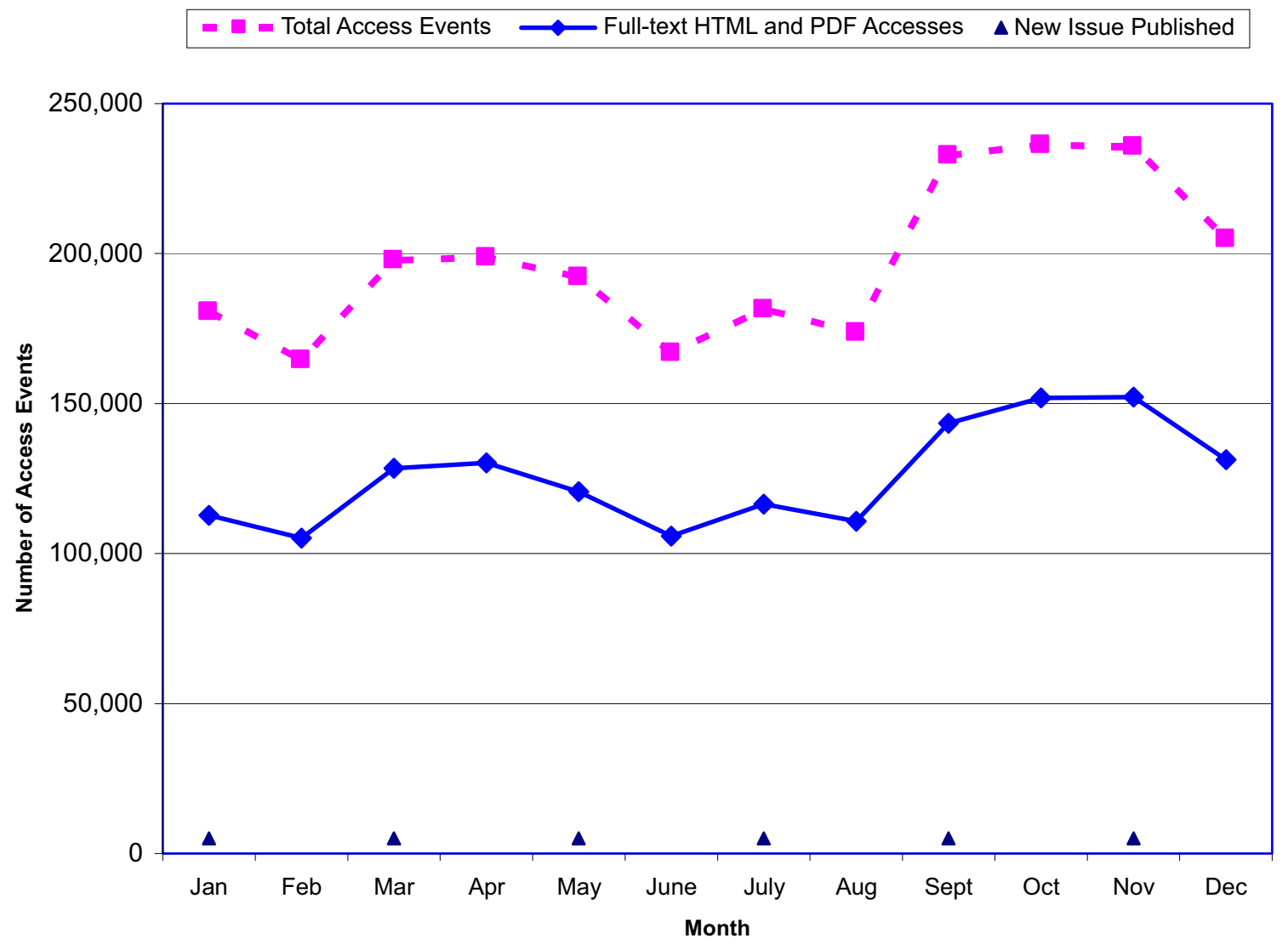




\begin{tabular}{|c|c|}
\hline 1. & $\begin{array}{l}\text { Margaret M. Eberl, Chester H. Fox, Stephen B. Edge, Cathleen A. Carter, Martin C. Mahoney } \\
\text { BI-RADS Classification for Management of Abnormal Mammograms }{ }^{2} \neq \\
\text { Article link: http://www.jabfm.org/cgi/content/full/19/2/161 }\end{array}$ \\
\hline 2. & $\begin{array}{l}\text { John W. Ely, Jerome A. Osheroff, M. Lee Chambliss, Mark H. Ebell } \\
\text { Approach to Leg Edema of Unclear Etiology } \neq \\
\text { Article link: http://www.jabfm.org/cgi/content/full/19/2/148 }\end{array}$ \\
\hline 3. & $\begin{array}{l}\text { John W. Ely, Colleen M. Kennedy, Elizabeth C. Clark, Noelle C. Bowdler } \\
\text { Abnormal Uterine Bleeding: A Management Algorithm }{ }^{4} \neq \\
\text { Article link: http://www.jabfm.org/cgi/content/full/19/6/590 }\end{array}$ \\
\hline 4. & $\begin{array}{l}\text { Celia M. Ross } \\
\text { Fish Oil versus Cod Liver Oil: Is Vitamin D a Reason to Go Back to the Future }{ }^{5} \neq \\
\text { Article link: http://www.jabfm.org/cgi/content/full/18/5/445-b }\end{array}$ \\
\hline 5. & $\begin{array}{l}\text { Anthony A. Mork, Scott M. W. Haufe, William B. Yancey } \\
\text { Sometimes (What Seems to Be) A Heart Attack Is (Really) A Pain In The Neck }{ }^{6} \neq \\
\text { Article link: http://www.jabfm.org/cgi/content/full/17/1/74 }\end{array}$ \\
\hline 6. & $\begin{array}{l}\text { Liana Gold, Helena Igra } \\
\text { Levofloxacin-Induced Tendon Rupture: A Case Report and Review of the Literature }{ }^{7} \neq \\
\text { Article link: http://www.jabfm.org/cgi/content/full/16/5/458 }\end{array}$ \\
\hline 7. & $\begin{array}{l}\text { Richard A. Deyo, Sohail K. Mirza, Judith A. Turner, Brook I. Martin } \\
\text { Overtreating Chronic Back Pain: Time to Back Off? } \\
\text { Article link: http://jabfm.org/cgi/content/full/22/1/62 }\end{array}$ \\
\hline 8. & $\begin{array}{l}\text { Saili Desai, Diana Aldea, Elisabeth Daneels, Manal Soliman, Amy S. Braksmajer, Colin P. Kopes-Kerr } \\
\text { Chronic Addiction to Dextromethorphan Cough Syrup: A Case Report }{ }^{\ddagger} \\
\text { Article link: http://www.jabfm.org/cgi/content/full/19/3/320 }\end{array}$ \\
\hline 9. & $\begin{array}{l}\text { Beloo Mirakhur, Marc McKenna } \\
\text { Recurrent Herpes Simplex Type } 2 \text { Virus (Mollaret) } \text { Meningitis }^{\mathbf{1 0}} \\
\text { Article link: http://jabfm.org/cgi/content/full/17/4/303 }\end{array}$ \\
\hline 10. & $\begin{array}{l}\text { Robert L. Hatch, Sejal Shah } \\
\text { Warthin Tumor: A Common, Benign Tumor Presenting as a Highly Suspicious Mass }{ }^{11} \\
\text { Article link: http://jabfm.org/cgi/content/full/18/4/320 }\end{array}$ \\
\hline 11. & $\begin{array}{l}\text { Alan B. Douglass, Edward T. Bope } \\
\text { Evaluation and Treatment of Posterior Neck Pain in Family Practice } \text { P }^{\mathbf{1 2}} \\
\text { Article link: http://www.jabfm.org/cgi/content/full/17/suppl_1/S13 }\end{array}$ \\
\hline 12. & $\begin{array}{l}\text { Andre F. Lijoi, Joanna Brady } \\
\text { Vasa Previa Diagnosis and Management }{ }^{13} \neq \\
\text { Article link: http://www.jabfm.org/cgi/content/full/16/6/543 }\end{array}$ \\
\hline 13. & $\begin{array}{l}\text { Paul L. Dassow } \\
\text { Measuring Performance in Primary Care: What Patient Outcome Indicators Do Physicians Value? }{ }^{14} \\
\text { Article link: http://jabfm.org/cgi/content/full/20/1/1 }\end{array}$ \\
\hline 14. & $\begin{array}{l}\text { James E. Lessenger, Steven D. Feinberg } \\
\text { Abuse of Prescription and Over-the-Counter Medications }{ }^{15} \neq \\
\text { Article link: http://www.jabfm.org/cgi/content/full/21/1/45 }\end{array}$ \\
\hline 15. & $\begin{array}{l}\text { Tamara J. Dominguez } \\
\text { It's Not a Spider Bite, It's Community-Acquired Methicillin-Resistant Staphylococcus aureus }{ }^{\mathbf{1 6}} \neq \\
\text { Article link: http://www.jabfm.org/cgi/content/full/17/3/220 }\end{array}$ \\
\hline 16. & $\begin{array}{l}\text { Jonathan A. Drezner, Brian J. Sennett } \\
\text { Subacromial/Subdeltoid Septic Bursitis Associated with Isotretinoin Therapy and Corticosteroid } \\
\text { Injection }{ }^{77} \neq \\
\text { Article link: http://www.jabfm.org/cgi/content/full/17/4/299 }\end{array}$ \\
\hline 17. & $\begin{array}{l}\text { John A. Astin, Shauna L. Shapiro, David M. Eisenberg, Kelly L. Forys } \\
\text { Mind-Body Medicine: State of the Science, Implications for Practice }{ }^{\mathbf{1 8}} \neq \\
\text { Article link: http://www.jabfm.org/cgi/content/full/16/2/131 }\end{array}$ \\
\hline 18. & $\begin{array}{l}\text { Thomas C. Rosenthal } \\
\text { The Medical Home: Growing Evidence to Support a New Approach to Primary Care }{ }^{19} \\
\text { Article link: http://jabfm.org/cgi/content/full/21/5/427 }\end{array}$ \\
\hline
\end{tabular}




\begin{tabular}{ll}
\hline 19. & Dwenda Gjerdingen \\
The Effectiveness of Various Postpartum Depression Treatments and the Impact of Antidepressant \\
Drugs on Nursing Infants ${ }^{20} \neq$ \\
Article link: http://www.jabfm.org/cgi/content/full/16/5/372 \\
Erika N. Ringdahl, Susan L. Pereira, John E. Delzell \\
Treatment of Primary Insomnia ${ }^{21} \neq$ \\
Article link: http://www.jabfm.org/cgi/content/full/17/3/212
\end{tabular}

*The most-read rankings are recalculated at the beginning of each month. Rankings are based on hits received by articles archived on the $7 A B F M$ website only.

'Data source: "The 20 Most Frequently Read Articles" for the fABFM, January 2009 through December 2009, HighWire Press; updated monthly (accessed March 4, 2009).

"This article was also on the 2008 list of "The 20 Most Read Articles."

shows that older articles maintain their value with 7ABFM readers. Three of the newest articles included on the list discuss the overtreatment of chronic back pain, ${ }^{8}$ recurrent herpes simplex type 2 virus (Mollaret meningitis), ${ }^{10}$ and a Warthin tumor that presented as a highly suspicious mass. ${ }^{11}$ Other newcomers include measuring performance in primary care ${ }^{14}$ and the medical home, ${ }^{19}$ which reflects the current interest in these topics.

Phillip Lupo, MLIS

Anne Victoria Neale, PhD, MPH

Marjorie A. Bowman, MD, MPA

\section{References}

1. Lupo P, Neale AV, Bowman MA. Introduction of more Editorial Board members and the most frequently read articles in 2008. J Am Board Fam Med 2009;22:234-8.

2. Eberl MM, Fox CH, Edge SB, Carter CA, Mahoney MC. BI-RADS classification for management of abnormal mammograms. J Am Board Fam Med 2006; 19:161-4.

3. Ely JW, Osheroff JA, Chambliss ML, Ebell MH. Approach to leg edema of unclear etiology. J Am Board Fam Med 2006;19:148-60.

4. Ely JW, Kennedy CM, Clark EC, Bowdler NC. Abnormal uterine bleeding: a management algorithm. J Am Board Fam Med 2006;19:590-602.

5. Ross CM. Fish oil versus cod liver oil: is vitamin $\mathrm{D}$ a reason to go back to the future. J Am Board Fam Pract 2005;18:445-6.

6. Mork AA, Haufe SMW, Yancey WB. Sometimes (what seems to be) a heart attack is (really) a pain in the neck. J Am Board Fam Pract 2004;17:74-7.

7. Gold L, Igra H. Levofloxacin-induced tendon rupture: a case report and review of the literature. J Am Board Fam Pract 2003;16:458-60.

8. Deyo RA, Mirza SK, Turner JA, Martin BI. Overtreating chronic back pain: time to back off? J Am Board Fam Med 2009;22:62-8.
9. Desai S, Aldea D, Daneels E, Soliman M, Braksmajer AS, Kopes-Kerr CP. Chronic addiction to dextromethorphan cough syrup: a case report. J Am Board Fam Med 2006;19:320-3.

10. Mirakhur B, McKenna M. Recurrent herpes simplex type 2 virus (Mollaret) meningitis. J Am Board Fam Med 2004;17:303-5.

11. Hatch RL, Shah S. Warthin tumor: a common, benign tumor presenting as a highly suspicious mass. J Am Board Fam Med 2005;18:320-2.

12. Douglass AB, Bope ET. Evaluation and treatment of posterior neck pain in family practice. J Am Board Fam Pract 2004;17(Suppl):S13-22.

13. Lijoi AF, Brady J. Vasa previa diagnosis and management. J Am Board Fam Pract 2003;16:543-8.

14. Dassow PL. Measuring performance in primary care: what patient outcome indicators do physicians value? J Am Board Fam Med 2007;20:1-8.

15. Lessenger JE, Feinberg SD. Abuse of prescription and over-the-counter medications. J Am Board Fam Med 2008;21:45-54.

16. Dominguez TJ. It's not a spider bite, it's community-acquired methicillin-resistant staphylococcus aureus. J Am Board Fam Pract 2004;17:220-6.

17. Drezner JA, Sennett BJ. Subacromial/subdeltoid septic bursitis associated with isotretinoin therapy and corticosteroid injection. J Am Board Fam Pract 2004;17:299-302.

18. Astin JA, Shapiro SL, Eisenberg DM, Forys KL. Mind-body medicine: state of the science, implications for practice. J Am Board Fam Pract 2003;16:131-47.

19. Rosenthal TC. The medical home: growing evidence to support a new approach to primary care. J Am Board Fam Med 2008;21:427-40.

20. Gjerdingen D. The effectiveness of various postpartum depression treatments and the impact of antidepressant drugs on nursing infants. J Am Board Fam Pract 2003;16:372-82.

21. Ringdahl EN, Pereira SL, Delzell JE. Treatment of primary insomnia. J Am Board Fam Pract 2004;17:212-9. 